\title{
Chemical composition, botanical evaluation and screening of radical scavenging activity of collected pollen by the stingless bees Melipona rufiventris (Uruçu-amarela)
}

\author{
TANiA M.S. SILVA ${ }^{1}$, CElso A. CAMARA ${ }^{1}$, ANTONiO C.S. LINS ${ }^{2}$, MARIA DE FÁtimA AGRA ${ }^{2}$, \\ EVA M.S. SILVA ${ }^{3}$, IGOR T. REIS ${ }^{3}$ and BRENO M. FREITAS ${ }^{3}$ \\ ${ }^{1}$ Departamento de Química, Universidade Federal Rural de Pernambuco, Rua Dom Manoel de Medeiros, s/n \\ Dois Irmãos, 52171-900 Recife, PE, Brasil \\ ${ }^{2}$ Laboratório de Tecnologia Farmacêutica, Universidade Federal da Paraíba, Caixa Postal 5009 \\ 58051-970 João Pessoa, PB, Brasil \\ ${ }^{3}$ Departamento de Zootecnia, CCA, Universidade Federal do Ceará, Caixa Postal 12168, 60021-970 Fortaleza, CE, Brasil \\ Manuscript received on January 16, 2008; accepted for publication on December 8, 2008; \\ presented by FERNANDO GALEMBECK
}

\begin{abstract}
Stingless bees in Brazil are indigenous and found all over the country. Bee pollen is used for its nutritional value in the human diet. It is made up of natural flower pollen mixed with nectar and bee secretions. In order to evaluate the chemical composition, free radical scavenging activity, and botanical origin, sample of pollen loads from stingless bee, Melipona rufiventris (Uruçu amarela) was studied. The EtOAc extract of pollen of Melipona rufiventris yielded the following compounds: $p$-hydroxycinnamic acid, dihydroquercetin, isorhamnetin, isorhamnetin-3-O-(6"-O-E- $p$ coumaroyl)- $\beta$-D-glucopyranoside, luteolin, and quercetin. This is the first report of the isolation of isorhamnetin-3-O(6"- $O$ - $E$ - $p$-coumaroyl)- $\beta$-D-glucopyranoside from pollen. The free radical-scavenging activities of different solvent extracts of pollen were determined using DPPH assay. This activity decreases in the order: EtOAc $>$ EtOH $>$ Hexane extract. It appears that the EtOAc extract of the pollen is a good scavenger of active oxygen species. The botanical evaluation of pollen loads showed the composition by two pollen types, with the dominant type (97.3\%) being Scoparia dulcis (L.) (Scrophulariaceae) and the minor one Senna obtusifolia (L.) Irwin \& Barneby (Fabaceae). This suggests a specific foraging behavior in Melipona rufiventris bees, even in an environment with such a rich botanical diversity as the Northeastern Brazil.
\end{abstract}

Key words: antioxidant activity, bee pollen, flavonoids, Melipona rufiventris, Uruçu amarela.

\section{INTRODUCTION}

The Meliponin is a bee group of more than 300 species encountered around the world. They are characterized as having social and bearing an atrophied and non-functional sting, which justifies their popular name of stingless bees (Roubik 1989). Stingless bees are found in tropical and sub-tropical regions of South and Central America, Africa, Southeastern Asia and Australia. In

Correspondence to: Tania Maria Sarmento Silva E-mail: sarmento@pq.cnpq.br
Brazil, they are indigenous and present all over the country, although species differ from region to region (Nogueira-Neto 1997, Lima-Verde and Freitas 2002).

Besides their importance as major pollinators of most wild plants and some cultivated species, honey and bee pollen of meliponins are also source of food, and medicines (geopropolis) and income to rural populations. There is a strong culture of bee keeping and using their products in Brazil and other parts of the world where these bees are native (Freitas 1999). 
One of their products, bee pollen, is used for its nutritional value in the human diet. It is made up of natural flower pollen mixed with nectar and bee secretions, and is rich in sugars, proteins, lipids, vitamins and flavonoids (3-5\% dry weight) (Tomas-Lorente et al. 1992). Although bee pollen found in the market is harvested from honey bee (Apis mellifera) colonies, many other social bee species also collect and use pollen, such as the stingless bees (Nogueira-Neto 1997).

During ancient times, people throughout the world commonly used pollen, for the goodness and medicinal properties. Some of the reasons why ancient people used bee-pollen are the same for its use today. To date, no scientific evidence has been cited to disprove the claimed properties of bee-pollen (Campos et al. 1997). In recent years, the physiological functionality of natural foods has received much attention, due to increasing interest in human health. Among natural products, honey beederived apicultural products such as pollen and propolis have been applied for centuries in traditional medicine as well as in food diets and supplementary nutrition (Kroyer and Hegedus 2002). Much work has been conducted on the chemistry and properties of propolis and pollen. Hundreds of chemical compounds have been identified from them. In general, compared to many standard human foods, pollens are rich in protein, low in fat and possess a wealth of minerals and vitamins (Campos et al. 1996).

Reactive oxygen species (ROS) are produced in all mammalian cells as the result of normal cellular metabolism and due to the activation of oxidant-producing enzymes in response to exogenous stimulus. The balance between ROS production and antioxidant defenses determines the degree of oxidative stress. Generation of ROS has been associated with cell signaling, stress responses, cell proliferation, aging, and cancer development. The ability of ROS to induce cellular damage and to cause cell death opens the possibility to utilize this property in the treatment of cancer through a free radical mediated mechanism (Villamor et al. 2004). It has been reported that both pollen and propolis extracts and their respective isolated compounds have free radical scavenging activity (Campos et al. 2003, Kumazawa et al. 2004).

The major aim of the present study is to determine the chemical composition and the antiradical activity of pollen loads collected and processed by stingless bee Melipona rufiventris. In a previous work the chemical composition of the closely related solitary bee species Melipona subnitida Ducke was studied (Silva et al. 2006). Both species, among others, are endangered by extinction, mostly because their native environments are being destructed, and is well documented the sharp foraging range of these species (Gathmann and Tscharntke 2002).

\section{MATERIALS AND METHODS}

SAMPLE

The pollen loads of Melipona rufiventris known as uruçu-amarela was collected directly from pollen pots of four Melipona rufiventris colonies kept in Pacoti $\left(4^{\circ} 13^{\prime} 40^{\prime \prime} \mathrm{S}, 38^{\circ} 55^{\prime} 17^{\prime \prime} \mathrm{W}, 830 \mathrm{~m}\right.$ above sea level) State of Ceará, Brazil, in 2003.

\section{EXTRACTION AND SEPARATION}

Pollen loads of Melipona rufiventris (67.6 g) were extracted with EtOH in an ultrasound bath and the extract filtered and concentrated under reduced pressure. The crude residue was dissolved in $\mathrm{MeOH}: \mathrm{H}_{2} \mathrm{O}$ (7:3) and fractioned with n-hexane and then with EtOAc. These solvents were evaporated to dryness. The EtOAc fraction (6.1 g) was subsequently submitted to column chromatography using Sephadex ${ }^{\circledR}$ LH-20 and $\mathrm{MeOH}$ as elution system. The collected flavonoid fractions were analyzed by commercial TLC aluminum sheets (Merck silica gel $60 \mathrm{~F}_{254}$ ), with the spot visualization done with spraying diphenylboryloxyethylamine (NP) solution in $\mathrm{MeOH}$ and observing under UV light (366 nm). The EtOAc extract of the pollen of Melipona rufiventris yielded the phenolics, $\mathbf{1}(1.1 \mathrm{mg}), \mathbf{2}(10.0 \mathrm{mg}), \mathbf{3}$ $(28.0 \mathrm{mg}), \mathbf{4}(15.0 \mathrm{mg}), \mathbf{5}(5.0 \mathrm{mg})$, and $\mathbf{6}(10.0 \mathrm{mg})$.

\section{Free RADICAL-SCAVENGER ACTIVITY}

The free radical-scavenger activity was determined by the 1,1-diphenyl-2-picrylhydrazyl (DPPH) assay, as described previously (Silva et al. 2006). The antiradical activity of the EtOH extract, hexane and EtOAc fractions were evaluated using a dilutions series (with the use of ethanol as solvent in all cases), in order to obtain a large spectrum of sample concentrations. This involved the 


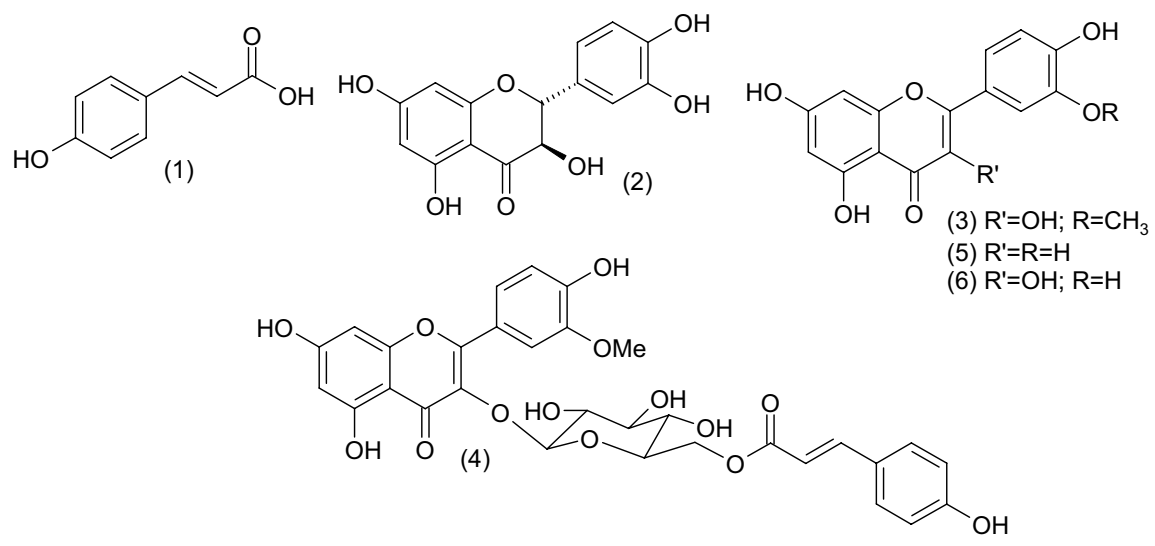

Fig. 1 - Compounds isolated from the pollen loads of stingless bee Melipona rufiventris.

mixing of $2 \mathrm{~mL}$ of DPPH solution $(100 \mu \mathrm{M}$ in ethanol) with an appropriate amount of extract or compound, followed by homogenization. After $30 \mathrm{~min}$, quantify of the remaining DPPH radicals was recorded from absorption at $\lambda 517 \mathrm{~nm}$. Three analytical replicates $(\mathrm{n}=3)$ were carried out on each extract for antiradical activity determinations. Measurements were averaged, and the results are given as mean \pm standard deviation (S.D.). Antiradical efficiency was established using regression analysis at a 95\% significance level $(\mathrm{P}<0.05)$. Results are presented in $\mathrm{EC}_{50}$ values, which represent the concentration of sample required to scavenge $50 \%$ of the DPPH radicals available (Table I). The reference standard were ascorbic acid $(\mathrm{EC} 50=2.48 \pm 0.03 \mu \mathrm{g} / \mathrm{mL})$ and butylated hydroxyl toluene BHT $(4.47 \pm 0.08 \mu \mathrm{g} / \mathrm{mL})$.

\section{Botanical Origin of the Pollen LoAds}

Samples of pollen loads (2.0 g) were hydrated in water in order to free pollen grains from the loads mass. After being completely homogenized, they were washed, centrifuged and mounted in glycerin jelly according to the method of Maurizio and Louveaux (1965). Five slides with glycerin jelly were mounted from each sample. Pollen grains were counted (500 per slide, at least) to establish the identity and frequency of the pollen types. Pollen types were identified by comparison with slides from the palynotheca of the Bee Laboratory (Universidade Federal do Ceará, Brazil).

Pollen types were classified according to their frequency in the sample into dominant ( $>45 \%)$, accessory
$(45 \%<\mathrm{X}>3 \%)$ and isolated $(<3 \%)$ (Maurizio and Louveaux 1965).

\section{RESULTS AND DISCUSSION}

\section{IDENTIFICATION OF THE COMPOUNDS}

The NMR spectra were used to identify the structures of the phenolics isolated from pollen loads of Melipona rufiventris as $p$-hydroxycinnamic acid (1), dihydroquercetin (2), isorhamnetin (3), isorhamnetin-3-O-(6"-O$E$ - $p$-coumaroyl)- $\beta$-D-glucopyranoside (4), luteolin (5), and quercetin (6), Figure 1. Their spectral data, particularly ${ }^{13} \mathrm{C} \mathrm{NMR}$, were in close agreement with literature values, for dyhydroquercetin, isorhamnetin, luteolin and quercetin (Agrawal 1989, Markham and Chari $1982)$, and for isorhamnetin-3-O-(6"-O-E-p-coumaroyl)- $\beta$-D-glucopyranoside (4) (Romussi et al. 1988). Table I showed the ${ }^{1} \mathrm{H}$ and ${ }^{13}$-NMR data for compound 4.

Flavonoids are widely recognized as reliable chemotaxonomic markers in plants in general (Emerenciano et al. 2001, Harborne and Turner 1984). Recently, this evidence was obtained for pollen flavonoids (Campos et al. 1997) and has been recognized previously as potentially useful taxonomic markers (Meurer 1988, Tomas-Lorente 1992). In addition, pollen flavonoids are arguably quality factors in terms of their phytotherapeutic value as antioxidants and radical scavengers (Pietta 2000, Cook and Samman 1996), and their involvement as essential components in pollen germination and pollen tube grown (Ylstra et al. 1992).

With the exception of the acylated flavonoid, iso- 
TABLE I

The ${ }^{1} \mathrm{H}$ and ${ }^{13} \mathrm{C}$-NMR data of compound 4 (DMSO- $d_{6}$ ).

\begin{tabular}{|c|c|c|}
\hline No. & $\mathrm{C}$ & $\mathrm{H}\left(J_{\mathrm{Hz}}\right)$ \\
\hline 2 & 155.98 & \\
\hline 3 & 132.91 & \\
\hline 4 & 177.17 & \\
\hline 5 & 162.50 & \\
\hline 6 & 99.18 & $6.12(\mathrm{sl})$ \\
\hline 7 & 165.62 & \\
\hline 8 & 93.83 & $6.34(\mathrm{sl})$ \\
\hline 9 & 156.46 & \\
\hline 10 & 103.44 & \\
\hline $1^{\prime}$ & 120.93 & \\
\hline 2 ' & 113.26 & $7.86(\mathrm{~d}, 2.0)$ \\
\hline $3^{\prime}$ & 149.64 & \\
\hline 4, & 146.92 & \\
\hline 5 , & 115.26 & $6.87(\mathrm{~d}, 7.6)$ \\
\hline 6 ' & 122.27 & $7.50(\mathrm{~d} 1,8.2)$ \\
\hline $\mathrm{OCH}_{3}$ & 55.71 & $3.83(\mathrm{~s})$ \\
\hline $1 "$ & 101.15 & $5.52(\mathrm{~d}, 7.0)$ \\
\hline $2^{\prime \prime}$ & 74.28 & $3.26(\mathrm{~m})$ \\
\hline 3 ', & 76.25 & $3.28(\mathrm{~m})$ \\
\hline 4, & 70.07 & $3.18(\mathrm{~m})$ \\
\hline 5, & 74.28 & $3.41(\mathrm{~m})$ \\
\hline \multirow{2}{*}{$6^{\prime \prime}$} & 62.99 & $4.27(\mathrm{~m})$ \\
\hline & & $4.10(\mathrm{~m})$ \\
\hline $1, "$, & 124.85 & \\
\hline $2^{\prime \prime \prime}$ & 130.22 & $7.35(\mathrm{~d}, 8.0)$ \\
\hline $3^{\prime \prime \prime}$ & 115.84 & $6.77(\mathrm{~d}, 8.4)$ \\
\hline $4, "$, & 161.13 & \\
\hline $5, \%$ & 115.84 & $6.77(\mathrm{~d}, 8.4)$ \\
\hline $6, "$, & 130.22 & $7.35(\mathrm{~d}, 8.0)$ \\
\hline $7^{\prime \prime \prime}$ & 144.78 & $7.30(\mathrm{~d}, 16.2)$ \\
\hline $8,$, & 113.46 & $6.03(\mathrm{~d}, 16.0)$ \\
\hline $9, \prime$ & 166.27 & \\
\hline
\end{tabular}

rhamnetin-3- $O$ - (6"- $O$ - $E$ - $p$-coumaroyl) - $\beta$-D-glucopyranoside isolated from pollen loads collected by Melipona rufiventris we isolate and report only flavonoid aglycone. This profile of flavonoid distribution has been shown also in other stingless bee-pollens as Melipona subnitida (Silva et al. 2006), and Scaptotrigona bipunctata (Lins et al. 2003).

Dihydroquercetin (Strohl and Seikel 1965), isorhamnetin (Tomas-Lorente et al. 1992), and luteolin (Campos et al. 2002), have already been isolated from pollen. This is however the first report of isorhamnetin-3-O- (6"-O-E-p-coumaroyl) - $\beta$-D-glucopyranoside (4) in bee pollen.

Antiradical activity of EtOH extract, and hexane and EtOAc fractions of bee pollen according to the DPPH radical-scavenging method.

The free radical scavenging activities of different solvent extracts of pollen loads of Melipona rufiventris were determined using the DPPH assay. The results, expressed as $\mathrm{EC}_{50}$ values, were calculated by regression analysis as present in Table I (the correlation coefficients of the regression curves are also present in the Table). The EtOAc fraction showed potent free radicalscavenging activity on the DPPH radical compared to EtOH extract. The hexane extract was inactive $\left(\mathrm{EC}_{50}>\right.$ $500 \mu \mathrm{g} / \mathrm{mL})$.

The polyphenolics present in the EtOAc extract could be responsible for the activity. Quercetin, luteolin (Nessa et al. 2004), isorhamnetin and dihydroquercetin (Edenharder and Grunhage 2003) are already tested for the antiradicalar activity.

The complete assignment for compound (4) is showed in Table II and the corresponding chemical structure is shown in Figure 1.

TABLE II

$\mathbf{E C}_{50}$ values of different solvent extracts of pollen loads of Melipona rufiventris for free radicals scavenging, as assessed by DPPH radical-scavenging method.

\begin{tabular}{c|c|c}
\hline $\begin{array}{c}\text { Solvents extracts } \\
\text { of bee pollen }\end{array}$ & $\mathrm{EC}_{50}(\mu \mathrm{g} / \mathrm{mL}) \pm \mathrm{SD}^{\mathrm{a}}$ & $r$ \\
\hline EtOH & $104.1 \pm 1.2$ & 0.99 \\
\hline Hexane & $>500$ & \\
\hline EtOAc fraction & $15.3 \pm 0.4$ & 0.99 \\
\hline
\end{tabular}

Mean $\pm \mathrm{SD}(n=3)$; ${ }^{\mathrm{a}}$ The concentration sufficient to obtain $50 \%$ of a maximum scavenging capacity (procedure described in materials and methods). EC $_{50}$ values were calculated from regression curves, $r$ represents the correlation coefficient.

\section{BOTANICAL ORIGIN}

Bee pollen studied here, collected directly from hives, consisted of a mixture of pollen types of different species of plants. The pollen loads was composed by only two pollen types, where the dominant (97.3\%) type was Scoparia dulcis (L.) (Scrophulariaceae) and the isolated 
one Senna obtusifolia (L.) Irwin \& Barneby (Fabaceae) $(2.7 \%)$.

Mixture of different pollen types in one pollen bee is not common in social bees. Apis mellifera, a polylectic species, is known for its high fidelity to individual sources of pollen (Roubik 1989). Stingless bees are less generalist than $A$. mellifera in their foraging behavior (Nogueira-Neto 1997). Not surprisingly, only two pollen types were present in the pollen loads studied, suggesting that Senna obtusifolia contributed with little pollen and Scoparia dulcis was the major source of pollen to Melipona rufiventris in the observed period, even though the colonies were placed in an environment with a rich and varied flora, as in Brazilian Semi-Arid Northeast. This fact corroborates the foraging specificity to Melipona rufiventris.

\section{CONCLUSION}

In pollen loads of Melipona rufiventris the EtOAc mainly comprised of $p$-hydroxycinnamic acid, dihydroquercetin, isorhamnetin, isorhamnetin isorhamnetin-3-O-(6"$O$ - $E$ - $p$-coumaroyl)- $\beta$-D-glucopyranoside, luteolin, and quercetin. To the best of our knowledge, this is the first report of the isolation of isorhamnetin isorhamnetin-3$O$-(6"- $O$ - $E$ - $p$-coumaroyl)- $\beta$-D-glucopyranoside from pollen. The botanical evaluation of bee pollen showed that it was composed by two pollen types, with the dominant type (97.3\%) being Scoparia dulcis and the isolated one, Senna obtusifolia. This result suggests a specific foraging behavior in Melipona rufiventris bees, even in an environment as rich in diversity as the Northeastern Brazilian flora. The free radical scavenging effectiveness of the extracts showed that EtOAc extract was the most active. This is the first study of pollen loads from stingless bee Melipona rufiventris, a native species of Northeastern Brazil. The results of these trials will be helpful for the commercial production of the stingless bee-pollen for pharmaceutical or nutritional use. Other bioactivity determinations are now being carried out in order to give us more information about the potentiality of these pollens. It suggests that the extracts of the pollen are good scavengers of active oxygen species. This property of pollen seems to be important in the prevention of various diseases such as cancer, cardiovascular diseases, and diabetes, among others.

\section{ACKNOWLEDGMENTS}

The authors thank Conselho Nacional de Desenvolvimento Científico e Tecnológico (CNPq), Instituto do Milênio do Semi-Árido (IMSEAR), Rede Nordestina de Biotecnologia (RENORBIO), Coordenação de Aperfeiçoamento de Pessoal de Nível Superior (CAPES) and Programa Institucional de Bolsas de Iniciação Científica (PIBIC). The authors also thank Prof. J. Bhattacharyya (Laboratório de Tecnologia Farmacêutica - UFPB) for useful help in the preparation of the manuscript.

\section{RESUMO}

As abelhas sem ferrão são espécies indígenas encontradas em todo o Brasil. Seu pólen é utilizado devido ao seu valor nutricional na dieta humana. É produzido a partir de pólen floral misturado com néctar e líquidos secretados pelas abelhas. Visando avaliar a composição química, a atividade sequestradora de radicais livres e a origem botânica foi estudado o pólen coletado pela abelha sem ferrão Melipona rufiventris (Uruçu amarela). Do extrato acetato de etila foram isolados os compostos: ácido $p$-hidroxicinâmico, dihidroquercetina, isoramnetina, 3-O- (6"- $O$ - $E$ - $p$-coumaroil)- $\beta$-D-glicopiranosideo-isoramnetina, luteolina e quercetina. Esta é a primeira vez que a 3-O-(6"$O$ - $E$ - $p$-coumaroil)- $\beta$-D-glicopiranosideo-isoramnetina é isolada de pólen apícola. A atividade sequestradora de radicais livres de vários extratos com solventes diferentes foi determinada pelo teste com DPPH (difenil-picril-hidrazida). A atividade mostrou a ordem decrescente para os extratos AcOEt> EtOH $>$ Hexano. $\mathrm{O}$ extrato AcOEt apresenta melhor atividade sequestradora de radicais. A avaliação botânica palinológica mostrou que o pólen era composto de dois tipos, um majoritário (97.3\%) proveniente de Scoparia dulcis (L.) (Scrophulariaceae) e outro minoritário proveniente de Senna obtusifolia (L.) Irwin $\&$ Barneby (Fabaceae). Estes resultados sugerem o comportamento de forragem bastante específico exibido pela abelha Melipona rufiventris, mesmo em um ambiente tão rico em diversidade vegetal como o Nordeste do Brasil.

Palavras-chave: atividade antioxidante, pólen de abelha, flavonóides, Melipona rufiventris, Uruçu amarela.

\section{REFERENCES}

AgrawAL PK. 1989. Carbon- ${ }^{13}$ NMR of flavonoids. Elsevier: The Netherlands.

Campos M, Markham KR, Mitchell KA AND DA 
CUnHA AP. 1997. An approach to the characterization of bee pollens via their flavonoid/phenolic profiles. Phytochem Anal 8: 181-185.

Campos MG, Cunha A And Markham KR. 1996. Beepollen composition, properties, and applications. In: MIZRAhi A AND Lensky Y (Eds), Bee Products. Plenum Press: New York.

Campos MG, Webby RE and Markham KR. 2002. The unique occurrence of the flavone aglycone tricetin in myrtaceae pollen. Z Naturforsch C: J Biosc 57: 944-946.

Campos MG, WebBy RF, Markham KR, Mitchell KA AND DA CUNHA AP. 2003. Age-induced diminution of free radical scavenging capacity in bee pollens and the contribution of constituent flavonoids. J Agr Food Chem 51: 742-745.

CoOK NC AND SAMmAn S. 1996. Review: Flavonoids chemistry, metabolism, cardioprotective effects, and dietary sources. J Nutr Biochem 7: 66-76.

Edenharder R AND Grunhage D. 2003. Free radical scavenging abilities of flavonoids as mechanism of protection against mutagenicity induced by tert-butyl hydroperoxide or cumene hydroperoxide in Salmonella typhimurium TA102. Mutat Res-Gen Tox En 540: 1-18.

EmERENCIANo VP, Militao JSLT, CAMPos CC, RomofF P, Kaplan MAC, Zambon M And Brant AJC. 2001. Flavonoids as chemotaxonomic markers for Asteraceae. Biochem Syst Ecol 29: 947-957.

Freitas BM. 1999. A Vida das Abelhas. Craveiro \& Craveiro, Fortaleza, CE, Brasil CD-ROM.

Gathmann A And Tscharntke T. 2002. Foraging Ranges of Solitary Bees. J Anim Ecol 71: 757-764.

Harborne JB And Turner BL. 1984. Plant Chemosystematics London: Academic Press, p. 128-179.

Kroyer G And Hegedus N. 2002. Evaluation of bioactive properties of pollen extracts as functional dietary food supplement. Innovat Food Science Emerg Technol 2: 171-174.

Kumazawa S, Hamasaka T And Nakayama T. 2004. Antioxidant activity of propolis of various geographic origins. Food Chem 84: 329-339.

LIMA-VERDE LW AND FREITAS BM. 2002. Occurrence and biogeographic aspects of Melipona quinquefasciata in NE Brazil (Hymenoptera, Apidae). Braz J Biol 62: 479-486.
Lins ACS, Silva TMS, CAMARA CA, Silva EMS AND FrEITAS BM. 2003. Flavonoides isolados do polen coletado pela abelha Scaptotrigna bipunctata (canudo). Rev Bras Farmacogn 13: 40-41.

MARKhaM KR AND ChARI M. 1982. Carbon-13 NMR Spectroscopy of Flavonoids. In: HARBORNE JB AND MABRY TJ (Eds). Chapman \& Hall, London.

Maurizio A And Louveaux J. 1965. Pollens de plantes mellifères d'Europe. Union Group. Apic Fr Paris.

Meurer B. 1988. Phenylpropanoid patterns in fagales pollen and their phylogenetic relevance. Phytochemistry 27: 823-828.

Nessa F, Ismail Z, Mohamed N ANd Haris MRHM. 2004. Free radical-scavenging activity of organic extracts and of pure flavonoids of Blumea balsamifera DC leaves. Food Chem 88: 243-252.

Nogueira-Neto P. 1997. Vida e criação de abelhas indígenas sem ferrão. Nogueirapis, São Paulo, SP, Brasil 445 p.

Pietta PG. 2000. Flavonoids as antioxidants. J Nat Prod 63: $1035-1042$.

Romussi G, Bignardi G and Pizza C. 1988. Minor acylated flavonoids from Quercus cerris L. Liebigs Ann Chem 989-991.

RouBIK DW. 1989. Ecology and natural history of tropical bees. University Press: Cambridge, 514 p.

Silva TMS, CAmara CA, Lins ACS, Barbosa-Filho JM, Silva EM, Freitas BM AND SANTOS FAR. 2006. Chemical composition and free radical scavenging activity of pollen loads from stingless bee Melipona subnitida Ducke. J Food Compos Anal 19: 507-511.

Strohl MT And SEIKEL MK. 1965. Polyphenols of pine pollens. Phytochemistry 4: 383-399.

Tomas-Lorente F, Garcia-Grau MM, Nieto JL AND TOMAS-BARBERAN FA. 1992. Flavonoids from CistusLadanifer bee Pollen. Phytochemistry 31: 2027-2029.

Villamor N, Montserrat E and Colomer D. 2004. Cytotoxic effects of $\mathrm{B}$ lymphocytes mediated by reactive oxygen species. Curr Pharmaceut Design 10: 841-853.

Ylstra B, Touraev A, Moreno RMB, Stoger E, VAntunen AJ, Vicente O, Mol JNM And HeberLEBORS E. 1992. Flavonols stimulate development, germination, and tube growth of tobacco pollen. Plant Physiol 100: 902-907. 